\title{
Preliminary Investigation of an Installed Pilot-Scale Biological Nutrient Removal Technology (BNRT) for Sewage Treatment
}

\author{
Regina Damalerio ${ }^{1,2}$, Aileen OrbeCIDO ${ }^{1,2}$, Michael Angelo Promentilla ${ }^{1,2}$, Ramon Christian EuSEBIO ${ }^{3}$, Liza $^{2}$ \\ PATACSIL ${ }^{4}$, and Arnel BELTRAN ${ }^{1,2, *}$ \\ ${ }^{1}$ Chemical Engineering Department, De La Salle University, Manila, 2401 Taft Ave. Malate, Manila 1004 Philippines \\ ${ }^{2}$ Center for Engineering and Sustainable Development Research, De La Salle University, Manila, 2401 Taft Ave. Malate, Manila \\ 1004 Philippines \\ ${ }^{3}$ Chemical Engineering Department, University of the Philippines Los Baños, College 4031, Laguna, Philippines \\ ${ }^{4}$ Chemical Engineering Department, Malayan Colleges Laguna, Pulo Diezmo Road, Cabuyao City, Laguna 4025, Philippines
}

\begin{abstract}
Water utilities, commercial and industrial establishments are required to upgrade or install new treatment systems to comply with the revised effluent standards issued by the Department of Environment and Natural Resources - Environment Management Bureau (DENR - EMB) which now includes removal and monitoring of nutrients (nitrogen and phosphorus components). One solution is to utilize a biological nutrient removal technology (BNRT) system capable of removing nutrients from sewage. The on-going study aims to investigate the performance of the pilot-scale system in the removal of nutrients from sewage. The designed pilot-scale anaerobic-anoxic-oxic $\left(\mathrm{A}^{2} \mathrm{O}\right)$ process with a total hydraulic retention time of $8.37 \mathrm{hrs}$. was operated in an existing sewage treatment plant (STP). System modification was adapted to ensure continuous operation. Dissolved oxygen (DO) and temperature of each compartment were evaluated after 45 days of system modification. The DO of the anaerobic and oxic compartment remained within the required range, while the internal recycling flowrate and/or aeration must be adjusted to achieve a DO concentration of $0.20-0.50 \mathrm{mg} / \mathrm{L}$ in the anoxic compartment. The research is financially supported by the Philippine Council for Industry, Energy and Emerging Technology Research and Development of the Department of Science and Technology (PCIEERD Project No. 04176).
\end{abstract}

\section{Introduction}

Rapid urbanization has contributed to deteriorating water quality. It was reported that about millions of cubic meters of untreated wastewater are discharged to water bodies such as Manila Bay and Laguna Lake (The International Water Association, 2018). Untreated wastewater contains high concentration of nutrients such as nitrogen and phosphorus, resulting to several environmental issues such as eutrophication and fish kill (Falahti-Marvast and Karimi-Jashni, 2015; Majdi Nasab et al., 2016; Simeon, 2019)

Last 2016, the Department of Environment and Natural Resources - Environmental Management Bureau (DENR-EMB) released the Department Administrative Order (DAO) 2016 - 08 which limits nitrogen and phosphorus concentrations on effluent wastewater. (DENR, 2016) as shown in Table 1. All establishments are given a 5-year grace period to install or upgrade their wastewater treatment facilities to comply with the revised standards.
Table 1. Previous and Current Effluent Standards for Class C Waters (DENR, 2016)

\begin{tabular}{lccc}
\hline Parameters & \multicolumn{2}{c}{ DAO 1990-35 } & DAO 2016-08 \\
& OEI & NPI & \\
\hline $\mathrm{BOD}(\mathrm{mg} / \mathrm{L})$ & 80 & 50 & 50 \\
$\mathrm{COD}(\mathrm{mg} / \mathrm{L})$ & 50 & 100 & 100 \\
$\mathrm{NH}_{3}-\mathrm{N}(\mathrm{mg} / \mathrm{L})$ & - & - & 0.5 \\
$\mathrm{NO}_{3}-\mathrm{N}(\mathrm{mg} / \mathrm{L})$ & - & - & 14 \\
$\mathrm{PO}_{4}{ }^{3-}(\mathrm{mg} / \mathrm{L})$ & - & - & 1 \\
$\mathrm{TSS}(\mathrm{mg} / \mathrm{L})$ & 90 & 70 & 100 \\
\hline
\end{tabular}

Biological nutrient removal (BNR) systems are widely accepted in other countries. Examples of BNR systems are anoxic-oxic (AO), anaerobic-anoxic-oxic $\left(\mathrm{A}^{2} \mathrm{O}\right)$, University Cape Town (UCT), and 5-stage Bardenpho (5-BP) (Tchobanoglous et al., 2003; von Sperling, 2007; Xiang et al., 2014). The utilization of these systems has been studied extensively in several countries, especially in developing countries, for different wastewater characteristics, operating parameters, and system configuration. Fan et al. (2009) evaluated the performance of a modified 
anaerobic/anoxic/oxic $\left(\mathrm{A}^{2} \mathrm{O}\right)$ process for low strength wastewater treatment. $90 \%$ of the wastewater was fed to the anaerobic tank while the remaining $10 \%$ was fed to the pre-anoxic tank installed prior to the anaerobic tank. Return sludge was recycled back to the pre-anoxic tank instead of the anaerobic tank. At low strength wastewater, low total nitrogen removal was attained due to low nitrate recirculation rate and higher total phosphorus removal was attained when influent total phosphorus is above $1 \mathrm{mg} / \mathrm{L}$. Tran and Tran (2011) investigated the performance of $\mathrm{A} / \mathrm{O}-\mathrm{MBR}$ system for low-strength, high nutrient concentration domestic wastewater system in Hanoi, Vietnam. The system consists of anoxic and oxic compartments. The hollow fiber membrane was submerged in the oxic compartment. The system was operated at an influent flowrate of 10 $\mathrm{L} / \mathrm{hr}$ for 150 days. The system was able to remove $90 \%$ of influent COD and $96 \%$ of influent ammonia. Nitrogen removal increased at increasing return activated sludge (RAS) ratios. Xiang et al. (2014) investigated the performance of a full-scale $\mathrm{A}^{2} \mathrm{O}-\mathrm{MBR}$ for low carbon and nitrogen $(\mathrm{C} / \mathrm{N})$ ratio municipal wastewater treatment. The system was designed to treat $15,000 \mathrm{~m}^{3}$ of wastewater per day. Sodium acetate, an external carbon source, was added to increase the low $\mathrm{C} / \mathrm{N}$ ratio. Results showed that the addition of carbon source did not affect the COD removal only. The average removal efficiencies for $\mathrm{COD}, \mathrm{NH}_{4}{ }^{+}-\mathrm{N}, \mathrm{TN}$, and TP are $84.5 \%, 98.1 \%, 52.1 \%$, and $43.5 \%$, respectively.

Nutrient removal from wastewater occurs due to the role of certain microorganisms in converting organic matter into its simpler form. Nitrogen is removed from wastewater by nitrification then denitrification. Nitrification occurs at the oxic compartment where autotrophic bacteria convert ammonia $\left(\mathrm{NH}_{4}-\mathrm{N}\right)$ to nitrate $\left(\mathrm{NO}_{3}-\mathrm{N}\right)$. Meanwhile, the denitrification process allows facultative heterotrophic bacteria to convert nitrates to gaseous nitrogen. This occurs at the anoxic compartment where nitrates are consumed by the denitrifying bacteria as electron acceptor in the absence of oxygen (Tchobanoglous et al., 2003; von Sperling, 2007). Phosphorus removal occurs at the anaerobic and oxic zones. In the anaerobic zone, the polyphosphateaccumulating organisms release phosphates in the liquid medium as it assimilates the volatile fatty acids (VFAs) and produces poly- $\beta$-hydroxyalkanoate (PHAs). The release of phosphates supplies energy for the storage of PHAs. The stored PHAs are metabolized as soon as PAOs enter the oxic zone. Phosphates are assimilated by the cells and the energy released from PHA metabolism is used to cell production. Cells with high phosphate uptake are either removed as excess sludge or recycled back to the anaerobic zone (Tchobanoglous et al., 2003; von Sperling, 2007; Yuan et al., 2012).
To comply with the revised administrative order, all establishments are currently transitioning to using BNR technologies. The five-year grace period provides establishments to conduct research and evaluation in determining the suitable BNR technology to be used in different wastewater types here in the Philippines. It is proposed to evaluate in lab-scale to pilot-scale setting to provide insights in constructing large-scale facilities.

The objective of the study is to evaluate the performance of a designed pilot-scale BNR system in the removal of phosphates $\left(\mathrm{PO}_{4}{ }^{3-}\right)$, ammonia as nitrogen $\left(\mathrm{NH}_{3}-\mathrm{N}\right)$, and nitrates as nitrogen $\left(\mathrm{NO}_{3}-\mathrm{N}\right)$ for sewage treatment in the Philippines.

\section{Methodology}

\subsection{Design parameters for $A^{2} O$ design}

A pilot-scale anaerobic-anoxic-oxic $\left(\mathrm{A}^{2} \mathrm{O}\right)$ process was designed for an influent flowrate of $1 \mathrm{~m}^{3} /$ day. The influent and effluent wastewater characteristics used for the design was based on the medium-strength wastewater characteristics from Tchobanoglous et al., (2003) and Class C DAO 2016-08 Standards, respectively.

Several parameters are considered in designing a BNR process. For the tank design, parameters such as sludge age, sludge yield, endogeneous coefficient, mixed liquor suspended solids (MLSS) concentration, mixed liquor volatile suspended solids (MLVSS) concentration, hydraulic retention times, and size fraction of the anoxic and oxic tanks are determined. Sludge age should be between 5-10 days, and the MLSS and MLVSS concentration should be between $2000-4000 \mathrm{mg} / \mathrm{L}$.

The total oxygen requirement is computed by determining the oxygen demand during nitrification and denitrification. Parameters values of specific growth rate ( $\mu$ max), saturation coefficients, temperature and yield coefficients, denitrification rate, oxygen production, and fraction of ammonia in the sludge used in the design are based from von Sperling (2007).

Oxygen in the oxic compartment can be supplied either by mechanical aeration or by diffused air. Energy requirement is typically calculated in order to determine the more suitable and cost-effective. However, in the study, aeration by diffused air was utilized (Chen et al., 2011; Falahti-Marvast and Karimi-Jashni, 2015).

Lastly, the hydraulic retention time, diameter/sidewater depth, and bottom cone slope should be considered in the design of a final clarifier (or secondary sedimentation tank) (von Sperling, 2007).

The summary of the parameter values is provided in Table 1. 


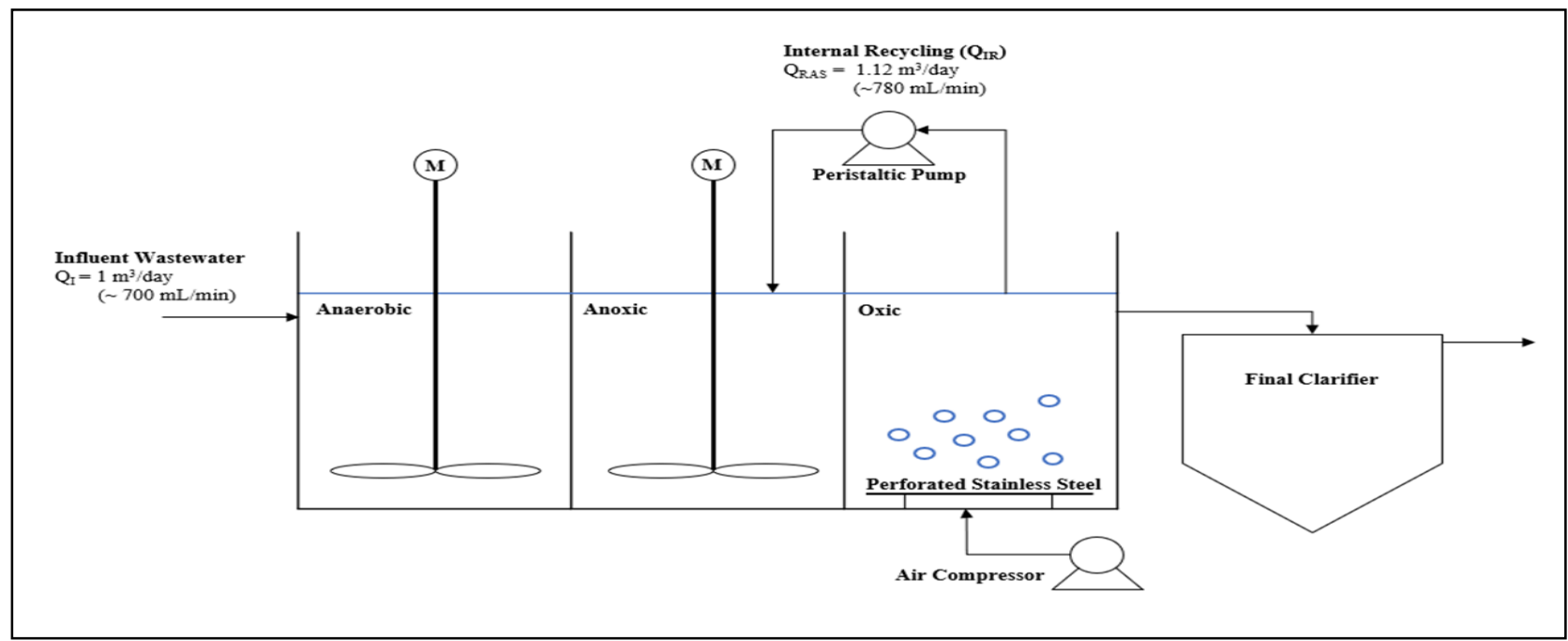

Figure 1. Schematic diagram of the $\mathrm{A}^{2} \mathrm{O}$ system.

\subsection{Influent wastewater characteristics and seed sludge}

The fabricated system was installed in an existing sewage treatment plant (STP) in Metro Manila. The influent wastewater of the system came from the effluent of the fine screening process. The inoculated activated sludge (MLSS $=2000 \mathrm{mg} / \mathrm{L}$ ) was collected from the aeration tank of the STP.

\subsection{Analytical measurements}

Meter devices will be utilized to measure in-situ parameters such as pH (Hanna Instruments, HI 98129), dissolved oxygen (DO) and temperature (Horiba Instruments DO120-K, Japan). Hach TNTplus vials will be used for parameters such as COD, ammonia as nitrogen, nitrate as nitrogen, and phosphates $(\mathrm{HACH}$, Germany) and its concentrations will be measured using HACH DR 1900 Portable Spectrophotometer. HACH DRB 200 Digital Reactor Block will be used for digestion of samples for COD and phosphate analysis.

\section{Methodology}

\section{$3.1 \mathrm{~A}^{2} \mathrm{O}$ design}

The parameter values in Table 2 were used to compute for tank dimensions. However, the dimensions and hydraulic retention times changed after fabrication. After fabrication, the pilot-scale BNR system, with a total volume of $348.6 \mathrm{~L}$ at tap water level, was divided into three compartments: anaerobic $(62.6 \mathrm{~L})$, anoxic $(79.2 \mathrm{~L})$, and oxic $(206.8 \mathrm{~L})$. The hydraulic retention times are 1.50 hours, 1.90 hours, and 4.97 hours, respectively. All HRT values, except for $\mathrm{HRT}_{\text {anoxic }}$, are within the range as shown in Table 2. The calculated height of the tank is 40 $\mathrm{cm}$, including the freeboard of $10 \mathrm{~cm}$ to prevent wastewater from overflowing. The width is $58 \mathrm{~cm}$, and each compartment has a length of $30 \mathrm{~cm}, 39 \mathrm{~cm}$, and 115 $\mathrm{cm}$.

Vertical flow mixers are installed in the anaerobic and anoxic compartments. The calculated power requirement for the mixer in the anaerobic and anoxic compartments are $95 \mathrm{~W}$ and $125 \mathrm{~W}$. However, supplied mixers have a power of $400 \mathrm{~W}$ and speed of $180 \mathrm{rpm}$. Since these mixers are too fast, intermittent mixing is carried out twice a week for 5-15 minutes.

Aeration by diffused air was chosen for oxygen supply in the oxic compartment. Air was supplied by compressor passes through the perforated stainless-steel rods installed at the bottom surface.

The total calculated volume of the final clarifier is $87.5 \mathrm{~L}$. It has an outer diameter of $83 \mathrm{~cm}$ and a height of $25.02 \mathrm{~cm}$. A freeboard of $10 \mathrm{~cm}$ was added to prevent overflowing from the outer perimeter. Its hydraulic residence time was calculated to be 2.10 hours. Peristaltic pumps were supplied to deliver influent wastewater and sludge to the anaerobic compartment, and to recycle wastewater from the oxic to anoxic compartment. Figure 1 above illustrates the schematic diagram of an $\mathrm{A}^{2} \mathrm{O}$ process.

\subsection{System modification}

Weekly inspection of the system was conducted to ensure continuous operation. During the operation (Days 0 - 45), several adjustments were done such as relocation of influent wastewater source, replacement of the mesh attached at the hose that draws influent wastewater to the system, and removal of floating sludge. After steady-state conditions, internal recycling pump was operated at a flowrate of $1.12 \mathrm{~m}^{3} /$ day $(780 \mathrm{~mL} / \mathrm{min})$. 
Table 2. Parameter Values Used in the Design of the $A^{2} O$ System (Tchobanoglous et al., 2003; von Sperling, 2007; Michigan Department of Environmental Quality Operator Training and Certification Unit, n.d.)

\begin{tabular}{|c|c|c|c|}
\hline Parameter & Unit & Range & Value \\
\hline \multicolumn{4}{|l|}{ Tank Design } \\
\hline Sludge Age & $\mathrm{d}$ & $5-10$ & 14 \\
\hline Sludge Yield & $\mathrm{g} \mathrm{VSS} / \mathrm{g} \mathrm{BOD}_{5}$ & $0.40-0.80$ & 0.6 \\
\hline Endogeneous Coefficient, $\mathrm{K}_{\mathrm{D}}$ & g VSS/g VSS-d & $0.06-0.10$ & 0.137 \\
\hline Temperature Coefficient for $K_{D}$ & - & $1.05-1.09$ & 1.07 \\
\hline MLSS & $\mathrm{mg} / \mathrm{L}$ & $2000-4000$ & 3750 \\
\hline MLVSS & $\mathrm{mg} / \mathrm{L}$ & $2000-4000$ & 3000 \\
\hline Fraction of Anoxic Tank & - & 0.25 & 0.25 \\
\hline Fraction of Oxic Tank & - & 0.75 & 0.75 \\
\hline \multicolumn{4}{|l|}{ Hydraulic Retention Time (HRT) } \\
\hline Anaerobic & $\mathrm{hr}$ & $0.50-1.50$ & 1.20 \\
\hline Anoxic & $\mathrm{hr}$ & $0.50-1.00$ & 1.58 \\
\hline Oxic & $\mathrm{hr}$ & $3.50-6.00$ & 4.73 \\
\hline \multicolumn{4}{|l|}{ Oxygen Requirements } \\
\hline \multicolumn{4}{|l|}{ Nitrification } \\
\hline$\mu_{\max }$ at $20^{\circ} \mathrm{C}$ & $\mathrm{d}^{-}$ & $0.30-0.70$ & 0.50 \\
\hline Temperature Coefficient & - & \multicolumn{2}{|c|}{1.10} \\
\hline $\begin{array}{l}\text { Ammonia Half-Saturation Coefficient, } \\
\mathrm{K}_{\mathrm{N}}\end{array}$ & $\mathrm{g} \mathrm{NH}_{4}{ }^{+} / \mathrm{m}^{3}$ & $0.50-1.00$ & 0.70 \\
\hline $\begin{array}{l}\text { Oxygen Half-Saturation } \\
\text { Coefficient }\left(\mathrm{K}_{0}\right)\end{array}$ & $\mathrm{g} \mathrm{O}_{2} / \mathrm{m}^{3}$ & $0.40-1.00$ & 0.80 \\
\hline Yield Coefficient for Nitrifiers $\left(\mathrm{Y}_{\mathrm{N}}\right)$ & $\mathrm{g}$ cells $/ \mathrm{g} \mathrm{NH}_{4}{ }^{+}$oxidized & $0.05-0.10$ & 0.08 \\
\hline Oxygen Demand & $\mathrm{g} \mathrm{O}_{2} / \mathrm{g} \mathrm{NH}_{4}^{+}$oxidized & \multicolumn{2}{|c|}{4.57} \\
\hline \multicolumn{4}{|l|}{ Denitrification } \\
\hline Denitrification Rate & $\mathrm{kg} \mathrm{NO}_{3}{ }^{-} / \mathrm{kg}$ VSS-d & $0.03-0.11$ & 0.08 \\
\hline Temperature Coefficient & - & $1.08-1.09$ & 1.09 \\
\hline Fraction of Ammonia in the Sludge & $\mathrm{kg} \mathrm{NH}_{4}^{+} / \mathrm{kg} \mathrm{VSS}$ & \multicolumn{2}{|c|}{0.12} \\
\hline $\mathrm{O}_{2}$ Savings & $\mathrm{g} \mathrm{O}_{2} / \mathrm{g} \mathrm{NO}_{3}{ }^{-}$reduced & \multicolumn{2}{|c|}{2.86} \\
\hline \multicolumn{4}{|l|}{ Parameters } \\
\hline$\alpha$ & - & \multicolumn{2}{|c|}{0.85} \\
\hline$\beta$ & - & \multicolumn{2}{|c|}{0.90} \\
\hline$\theta$ & - & \multicolumn{2}{|c|}{1.024} \\
\hline Specific Gravity of Air & $\mathrm{kg} / \mathrm{m}^{3}$ & \multicolumn{2}{|c|}{1.20} \\
\hline Fraction of $\mathrm{O}_{2}$ in Air & $\mathrm{g} \mathrm{O}_{2} / \mathrm{g}$ air & \multicolumn{2}{|c|}{0.23} \\
\hline \multicolumn{4}{|l|}{ Aeration by Diffused Air } \\
\hline $\mathrm{O}_{2}$ Transfer Efficiency & - & \multicolumn{2}{|c|}{0.15} \\
\hline Motor and Blower Efficiency & - & \multicolumn{2}{|c|}{0.60} \\
\hline \multicolumn{4}{|l|}{ Final Clarifier } \\
\hline Hydraulic Retention Time & $\mathrm{hr}$ & $2.00-3.00$ & 2.10 \\
\hline
\end{tabular}




\subsection{Dissolved Oxygen (DO) and Temperature measurement}

After flow stabilization and system adjustment, dissolved oxygen (DO) and temperature measurement started by day 45 . Figure 2 illustrates the decrease in temperature per compartment through time. This is attributed to the change in the weather in the Philippines as the rainy season usually starts by June.

It is critical to measure the dissolved oxygen (DO) concentration per compartment for effective nitrogen and phosphorus removal. von Sperling (2007) states that effective denitrification process occurs when DO is 0.20 $\mathrm{mg} / \mathrm{L}$ and nitrification process occurs when DO is from $0.50-4 \mathrm{mg} / \mathrm{L}$. Studies such as Falahti-Marvast and Karimi-Jashni (2015) and Majdi Nasab et al. (2016) maintained the DO concentration less than $0.50 \mathrm{mg} / \mathrm{L}$ for anaerobic and anoxic compartments of their BNRT systems.

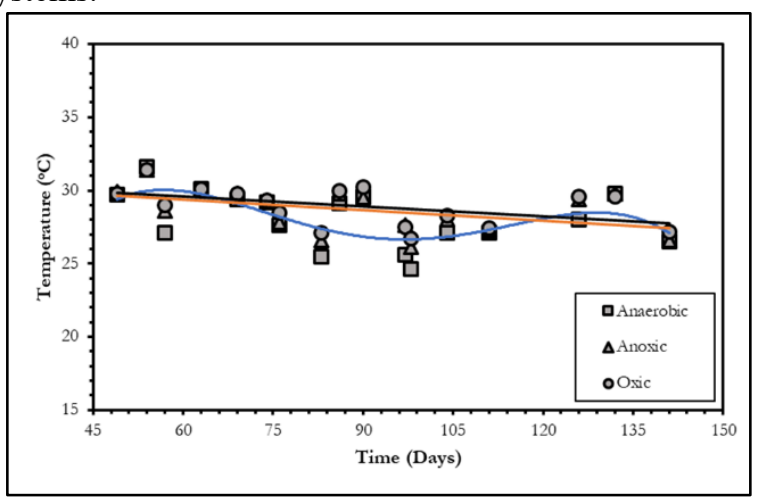

Figure 2. Temperature $\left({ }^{\circ} \mathrm{C}\right)$ versus time (days) of anaerobic, anoxic, and oxic compartments from day 46 onwards. The system is operated at $\mathrm{Q}_{\text {influent }}=1$ $\mathrm{m}^{3} /$ day and $\mathrm{Q}_{\mathrm{IR}}=780 \mathrm{~mL} / \mathrm{min}$.

The typical DO value in the oxic compartment is 2 $\mathrm{mg} / \mathrm{L}$, but some studies use DO concentrations of $3-4$ mg/L (von Sperling, 2007; Falahti-Marvast and KarimiJashni, 2015; Majdi Nasab et al., 2016). Figure 3 illustrates DO concentration per compartment through time. Based from the data, the DO in the anaerobic and oxic chambers are within the recommended range. The DO concentration at the anaerobic compartment was maintained below $0.40 \mathrm{mg} / \mathrm{L}$, except in day 76 where the mixer was operated continuously for two days. The DO in the anoxic compartment, however, was not maintained within the recommended range. The lowest concentration recorded was $0.53 \mathrm{mg} / \mathrm{L}$ and the highest was $2.74 \mathrm{mg} / \mathrm{L}$. The $\mathrm{DO}$ of the wastewater recycled from the oxic compartment increases the DO in the anoxic compartment.

\subsection{Evaluation of nutrient removal}

The performance of the system was evaluated for 150 days BOD, COD, and TSS reached the required effluent standards and were reduced by a maximum of $94.3 \%$, $73.9 \%$, and $99.3 \%$, respectively. The effluent $\mathrm{NO}_{3}-\mathrm{N}$ concentration increased from its initial average concentration of $0.62 \mathrm{mg} / \mathrm{L}$. Although the effluent concentration below the limit, the increase of $\mathrm{NO}_{3}-\mathrm{N}$

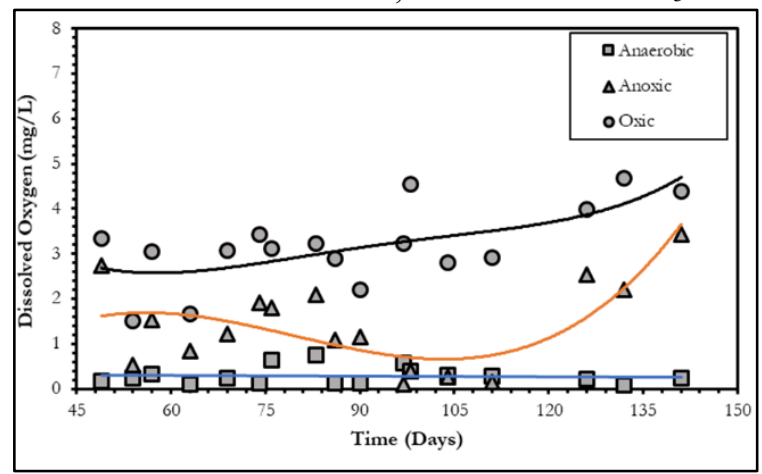

Figure 3. Dissolved oxygen concentration versus time (days) of anaerobic, anoxic, and oxic compartments from day 46 onwards. The system is operated at $\mathrm{Q}_{\text {influent }}=$ $1 \mathrm{~m}^{3} /$ day and $\mathrm{Q}_{\mathrm{IR}}=780 \mathrm{~mL} / \mathrm{min}$.

implied poor denitrification process in the anoxic compartment. Hence, modification should be done to adjust the DO to below $0.50 \mathrm{mg} / \mathrm{L}$. $\mathrm{NH}_{3}-\mathrm{N}$ and $\mathrm{PO}_{4}{ }^{3-}$ concentrations did not reach the required standards but decreased by a maximum of $59.5 \%$ and $69.4 \%$, respectively. The removal efficiencies for $\mathrm{NH}_{3}-\mathrm{N}$ and $\mathrm{PO}_{4}^{3-}$ are low compared to other studies (Fan et al., 2009; Tran and Tran, 2011; Xiang et al., 2014). Fan et al. (2009), Tran and Tran (2011) and Xiang et al. (2014) achieved $>95 \%$ removal of $\mathrm{NH}_{3}-\mathrm{N}$ for low strength wastewater. The low $\mathrm{NH}_{3}-\mathrm{N}$ removal efficiency may imply that there are insufficient nitrifiers in the system. On the other hand, the low phosphorus removal can be an indication that there is not enough carbon source for the PAOs. According to Xiang et al. (2014), the addition of an external carbon source can increase the phosphorus removal. However, some authors such as Fan et al. (2009) and Yuan et al. (2012), who did not add any external carbon source, mentioned that high phosphorus removal depends on the influent $\mathrm{COD} / \mathrm{P}$ ratio.

The performance of the system will be further investigated upon the installation and operation of the pump for return activated sludge.

\section{Conclusion}

The pilot-scale $\mathrm{A}_{2} \mathrm{O}$ system was designed based on several parameter values in the book of von Sperling (2007) and was installed at an existing sewage treatment plant to investigate its performance. Several modifications were required to ensure continuous system operation. The DO concentration in each compartment was measured and it was found out that DO concentration in the anoxic chamber did not fall within the required range. Adjustments can be done by lowering the recycling flowrate or decrease the aeration can be done. The removal efficiencies for BOD, COD, TSS, $\mathrm{NH}_{3}-\mathrm{N}$, and $\mathrm{PO}_{4}{ }^{3-}$ were $94.3 \%, 73.9 \%, 99.3 \%, 59.5 \%$ and $69.4 \%$, respectively. The effluent $\mathrm{NO}_{3}-\mathrm{N}$ concentration increased, implying the need to promote denitrification in the anoxic zone. Effluent $\mathrm{NH}_{3}-\mathrm{N}$ and 
$\mathrm{PO}_{4}{ }^{3-}$ decreased, however, it did not meet the current effluent standards. The low nutrient removal efficiency can be attributed to insufficient microorganisms and/or insufficient food source for the microorganisms. Phosphate removal of the system will be further investigated upon the operation of the return activated sludge (RAS) pump. Mixers should be replaced with lower speed to ensure homogeneous mixing of the solids in the anaerobic and anoxic zone. Finally, chemical precipitation for phosphorus removal may be conducted in future studies to compare the performance of chemical and biological phosphorus removal.

\section{Acknowledgements}

The research is financially supported by the Philippine Council for Industry, Energy and Emerging Technology Research and Development of the Department of Science and Technology (PCIEERD Project No. 04176).

\section{References}

Chen, Y., C. Peng, J. Wang, L. Ye, L. Zhang, and Y. Peng; "Effect of Nitrate Recycling Ratio on Simultaneous Biological Nutrient Removal in a Novel Anaerobic/Anoxic/Oxic $\left(\mathrm{A}^{2} / \mathrm{O}\right)-$ Biological Aerated Filter (BAF) System," Bioresource Technology, 102, 572-5727 (2011)

Department of Environment and Natural Resources (DENR); Water Quality Guidelines and General Effluent Standard of 2016 (DAO 2016-08) (2016)

Falahti-Marvast, H, and A. Karimi-Jashni; "Performance of Simultaneous Organic and Nutrient Removal in a Pilot Scale Anaerobic-Anoxic-Oxic Membrane Bioreactor System Treating Municipal Wastewater with a High Nutrient Mass C/N Ratio Municipal Wastewater Treatment," Chinese Journal of Chemical Engineering, 22 (4), 447-454 (2014)

Yuan, Z., S. Pratt, and D. J. Batstone; "Phosphorus Recovery from Wastewater Through Microbial Processes," Current Opinion in Biotechnology, 23, 878-883 (2012)
Ratio," International Biodeterioration \& Biodegradation, 104, 363-370 (2015)

Fan, J., T. Tao, J. Zhang, and G. You; "Performance Evaluation of a Modified Anaerobic/Anoxic/Oxic $\left(\mathrm{A}^{2} \mathrm{O}\right)$ Process Treating Low Strength Wastewater," Desalination, 249, 822-827 (2009)

International Water Association; The Reuse Opportunity (2018)

Majdi Nasab, A. R., S. M. Soleymani, M. Nosrati, and S. M. Mousavi; "Performance Evaluation of a Modified Step-Feed Anaerobic/Anoxic/Oxic Process for Organic and Nutrient Removal," Chinese Journal of Chemical Engineering, 24, 394 403 (2016)

Michigan Department of Environmental Quality Operator Training and Certification Unit; Clarifier Calculations (n.d.)

Simeon, L. M. "Excessive Waste Blamed for Las Piñas, Parañaque Fish Kill," The Philippine Star, October 12, 2019 (2019)

Tran, T. V. N. and H. S. Tran; "The Application of A/O-MBR System for Domestic Wastewater Treatment in Hanoi," Journal of Vietnamese Environment, 1, 19-24 (2011)

Tchobanoglous, G., H. D. Stensel, R. Tsuchihashi, and F. Burton; Wastewater Engineering Treatment and Resource Recovery, $5^{\text {th }}$ Ed., MacGraw Hill, New York, USA (2003)

von Sperling, M; "Activated Sludge and Aerobic Biofilm Reactors," 5, 69, 99, 177 - 178, 180, London, UK (2007)

Xiang, H., X. Li, S. Hojae, Z. Shanfa, and Y. Dianhai; "Biological Nutrient Removal in a Full Scale Anoxic/Anaerobic/Aerobic/Pre-Anoxic-MBR Plant for Low 